Jurnal Bisnis dan Manajemen, Volume 22, No. 2, September 2021, p. 127-146

\title{
DETERMINANTS OF INDONESIAN GOVERNMENT SECURITIES YIELD USING VECM
}

\author{
Batara Maju Simatupang \\ STIE Indonesia Banking School, Indonesia
}

\begin{abstract}
This study aims to uncover the determinants' effect on the return rate of government securities (GS). This study's data uses the government bonds that can be traded with the ten-year tenor, and the time-horizon of the collected data spans from 2009:M1 to 2018:M6. The study methodology utilizes the vector error correction model (VECM) model to determine the short-term backward behavior, which refers to the situation where the short-term balances are corrected for the long-term balances. Additionally, it is also to reveal the relationship between the variables within the model. Thus, this study is to see whether GS's reciprocal level has been at the value of efficient return or not. The results show that the cointegrated determinants of the Bank Indonesia (BI) rate / seven days repo, outstanding tradable government bonds, Fitch Rating, exchange rate, sovereign country risk, and regional bond index positively affects the GS yield. In contrast, the determinants of Fitch Rating, exchange rate, sovereign country risk, and outstanding tradable government bond negatively influence GS yields. The implication of this research is that the Indonesian government securities are interdependent with the identified determinants; thus, the Indonesian government should maintain the movement of those determinants to ensure that its GS stays positive.
\end{abstract}

Keywords: Government Securities, Vector Error Correction Model, Yields

\section{DETERMINAN OBLIGASI PEMERINTAH INDONESIA MENGGUNAKAN VECM}

\begin{abstract}
ABSTRAK
Penelitian ini bertujuan untuk mengungkap pengaruh determinan terhadap tingkat pengembalian Obligasi Pemerintah. Data penelitian ini menggunakan obligasi pemerintah yang dapat diperdagangkan dengan tenor sepuluh tahun, dan periode data yang dikumpulkan dari 2009M1 hingga 2018M6. Dalam mengungkap pengaruh determinan, digunakan model Vector Error Correction Model (VECM), yaitu untuk menentukan perilaku jangka pendek yang tertinggal, dimana keseimbangan jangka pendek selalu dikoreksi untuk keseimbangan jangka panjang. Selain itu, model ini juga digunakan untuk menjelaskan hubungan antar variabel dalam model. Adapun implikasi dari penelitian ini adalah untuk melihat apakah tingkat reciprocal Obligasi Pemerintah (GS) sudah berada pada nilai tingkat pengembalian yang efisien atau belum. Hasil pengujian VECM menemukan bahwa determinan kointegrasi adalah suku bunga Bank Indonesia (BI) / repo 7 hari, outstanding obligasi pemerintah yang dapat diperdagangkan, Fitch Rating, nilai tukar, sovereign country risk, dan indeks obligasi regional. BI rate / repo 7 hari dan indeks obligasi regional berpengaruh positif terhadap yield SUN. Sebaliknya, Peringkat Fitch, nilai tukar, risiko Sovereign Country, dan obligasi pemerintah yang dapat diperdagangkan memiliki pengaruh negatif terhadap imbal hasil Obligasi Pemerintah. Implikasi dari riset ini ialah tingkat obligasi pemerintah saling bergantung terhadap determinan yang telah teridentifikasi. Hal tersebut karena pemerintah Indonesia disarankan untuk menjaga dan memastikan determinan tersebut terkendali dalam rangka menjaga imbal hasil obligasi pemerintah tetap positif.
\end{abstract}

Kata-kata Kunci: Obligasi Pemerintah, Vector Error Correction Model, dan Imbal-balik.

Correspondent: Dr. Ir. Batara Maju Simatupang, MT. MPhil. CIMBA®. STIE Indonesia Banking School. Gedung Indonesia Banking School, Jl. Kemang Raya No. 35, Jakarta Selatan 12730, Indonesia. Email : batara.ms@ibs.ac.id.

Submitted: March 2021, Accepted: September 2021, Published: September 2021

ISSN: 1412 - 3681 (printed), ISSN: 2442 - 4617 (online), Website: http://journal.feb.unpad.ac.id/index.php/jbm 
Jurnal Bisnis dan Manajemen, Volume 22, No. 2, September 2021, p. 127-146

\section{INTRODUCTION}

According to the report published by the Directorate General of Financing and Risk Management (DGFRM) Ministry of Finance of the Republic of Indonesia (2018), it is shown that the determinants of the ten-years Government Securities (GS) yield rate are the currency exchange rate, the interest rates, inflation rates, credit default swap rates, and the growth of gross domestic product (GDP). Under this context, the level of GS yields of the Indonesian government is still considered higher than the other member of the Association of Southeast Asian Nations (ASEAN), which stands at the level of $8.3 \%$ in comparison to Thailand (2.7\%), the Philippines (3.9\%), Malaysia (4.1\%), and Vietnam (6.9\%); moreover, when compared to the other emerging markets, the average ten-year of the Indonesian GS yield is higher than India (7.8\%), although it is still lower compared to Turkey and Brazil at the GS yield level of $9.6 \%$ and $14.3 \%$ respectively (ASEAN Secretariat, 2018).

In actuality, the Indonesian government prefers the scenario that enables them to reduce the loans within the state budget finance and annually increase the GS issuance. As such, it is implied that the proportion of loans are decreasing comparably to its GS. That is, the financing of the GS interest will also increase along with the interest rate underlying the issuance of the respective GS.

The efficiency of applying an interest rate to GS is depended on what determinants affect the pricing of GS. In which each member of
ASEAN can compete in regards to their GS interest rate.

The effective yield is essential for the government because it involves the financing for the intended GS. This relationship can be seen in the proportion between loans and GS, as shown in Table 1.

Table 1. Outstanding Government Debt Position, June 2018

\begin{tabular}{|c|c|c|c|}
\hline \multirow[b]{2}{*}{ Instruments } & \multicolumn{2}{|c|}{ Nominal } & \multirow[b]{2}{*}{$\%$} \\
\hline & $\begin{array}{c}\text { Billion } \\
\text { USD }\end{array}$ & $\begin{array}{l}\text { Trillion } \\
\text { IDR }\end{array}$ & \\
\hline A. Loan & 56.56 & 814.74 & 19.14 \\
\hline Foreign Loans & 56.19 & 809.41 & 19.01 \\
\hline $\begin{array}{l}\text { Government } \\
\text { securities }\end{array}$ & 0.37 & 5.33 & 0.13 \\
\hline $\begin{array}{l}\text { B. Government } \\
\text { securities }\end{array}$ & 239.01 & $3,442.64$ & 80.86 \\
\hline $\begin{array}{l}\text { Government } \\
\text { securities }\end{array}$ & 196.36 & $2,828.38$ & 66.43 \\
\hline $\begin{array}{l}\text { State sharia } \\
\text { securities }\end{array}$ & 42.65 & 614.23 & 14.43 \\
\hline Total & 295.57 & $4,257.38$ & 100.00 \\
\hline $\begin{array}{l}\text { Note: Nominal bas } \\
30,2018 \\
\text { Source: DGFRM } \\
\text { of Indonesia ( } 2018\end{array}$ & $\begin{array}{l}\text { on the ex } \\
\text { istry of } F\end{array}$ & ange rate $\mathrm{o}$ & $\begin{array}{l}\text { June } \\
\text { epublic }\end{array}$ \\
\hline
\end{tabular}

As shown in Table 1, the GS composition as of June 2018 has reached Rp. 3,442.64 trillion. The value of the GS composition is equivalent to $80.86 \%$ of the Indonesian total debt (i.e., Rp. 4,257.38 trillion). More precisely, the GS that affects the efficiency of the return rate is tradable.

A similar pattern can also be seen within the government tradable securities, as shown in Table 2. In this regard, the Indonesian tradable securities have reached Rp. 3,210.64 trillion. This is equivalent to the $31.57 \%$ and $68.43 \%$ of the Indonesian outstanding tradable securities denominated in foreign and local securities. Conclusively, it can be said that that the 
Jurnal Bisnis dan Manajemen, Volume 22, No. 2, September 2021, p. 127-146

Table 2. Outstanding Tradable Securities Position, June 2018

\begin{tabular}{|c|c|c|c|c|}
\hline Government Tradable Securities & \multicolumn{2}{|c|}{$\begin{array}{l}\text { Outstanding in } \\
\text { Foreign Exchange }\end{array}$} & & Outstanding in IDR \\
\hline \multicolumn{5}{|l|}{ IDR Denominated } \\
\hline Zero Coupon & & & IDR & $75,000,000,000,000$ \\
\hline Fixed Coupon & & & IDR & $1,707,124,691,000,000$ \\
\hline Variable Coupon & & & IDR & $1,842,638,516,000,000$ \\
\hline \multicolumn{5}{|l|}{ US Dollar Denominated } \\
\hline Fixed Coupon & USD & $42,050,000,000$ & IDR & $600,095,550,000,000$ \\
\hline \multicolumn{5}{|l|}{ Japan Yen Denominated } \\
\hline Fixed Coupon & JPY & $555,000,000,000$ & IDR & $71,935,048,500,000$ \\
\hline \multicolumn{5}{|l|}{ Euro Denominated } \\
\hline Fixed Coupon & EUR & $7,300,000,000$ & IDR & $120,492,778,000,000$ \\
\hline \multicolumn{5}{|l|}{ B. Government Debt Securities } \\
\hline \multicolumn{5}{|l|}{ Rupiah Denominated } \\
\hline Zero Coupon & & & IDR & $26,430,000,000,000$ \\
\hline Fixed Coupon & & & IDR & $327,846,551,000,000$ \\
\hline \multicolumn{5}{|l|}{ USD Denominated } \\
\hline Fixed Coupon & USD & $15,500,000,000$ & IDR & $221,200,500,000,000$ \\
\hline Total Tradable Securities & & & $\overline{I D R}$ & $\overline{3,210,638,943,500,000}$ \\
\hline
\end{tabular}

Source: DGFRM Ministry of Finance of the Republic of Indonesia (2018)

Indonesian GS issuance has direct implications to the public funds, especially to the market share of the national banks.

Outstanding tradable securities dominated in foreign currencies have reached $31.57 \%$, which indicates the ability to access the foreign market's funds (i.e., the integration of the world financial market). In line with the research of Barr and Priestley (2004), it indicates strong evidence that the national markets are only partly integrated with the world markets.

In a similar context, Kim, Moshirian, and $\mathrm{Wu}$ (2006) examined the relationship between government bonds (and stocks) to assess the financial market integration. It is found that the declining trend in conditional correlations varies between the bond returns (and stock markets) within the European countries, Japan, and the United States (US). In a follow-up study, Lamedica and Reno (2007) extend the research of Barr and Priestley (2004) under the context of the Economic and Monetary Union (EMU), and the findings show that there is higher integration in all countries apart from Japan.

Mehra (1998) also examined the effect of interest rate on the US government bonds in 1962-1996, and it is found that real inflation has a relationship with the bonds interest rate in the long run. Such relationship is also reflected in the research conducted by Lemmen (1990), which 
Jurnal Bisnis dan Manajemen, Volume 22, No. 2, September 2021, p. 127-146

shows that the bond yields issued by the government of Australia, Canada, and Germany are depended on whether the ratio of government debt to GDP is positive or not. By which, such findings are further reinforced by Lemmen and Goodhart (1999) and Codogno, Favero, and Missale (2014) which shows the differences are positively dependent on the level of public debt. Moreover, Heppke-Falk and Hüfner (2004) found that the deficit was expected to positively impact spread yields in Germany, France, and Italy.

Following the relationship between the macroeconomic aspects and investment, it arises the issue of investment attractiveness. According to Hubbard (2001), the variables that can shift the demand curve for funds and cause the interest rates to rise are the increase in the expectation of return on investment, tax subsidies, inflations, and government budget deficit. Furthermore, the variables that can shift the demand curve that affects the interest rate (yield) to fall are the increase of tax and the reduction of interest to invest. Approprietly, the focus of this study is the determinants on GS return rates with the ten-year tenor.

Taking into account the findings of the previoust studies, it is revealed that (1) the DGFRM Ministry of Finance of the Republic of Indonesia (2018) established the determinants of the ten-years GS yield with the currency exchange rate, interest rates, inflation rates, credit default swap rates, and GDP growth, (2) for the short term GS, it is positively influenced by the bond liquidity, tenor, and inflation; However, the Bank Indonesia (BI) rate is negatively influenced it, (3) For the long-term GS, it is positively influenced by the bond liquidity, tenor, BI rate, Customer Price Index (CPI), inflation, and the real interest rate, and lastly, (4) the ability to access fundamental internal and external economic factors determine the international bond market.

This study's problem is the determinants that affect the GS varied, so testing is required by adding the factors or determinants that meet internal and external aspects. As a novelty in this research, determinants will be added, including the Indonesia sovereign index, oil price, and regional as external factors, and country risk as internal factors. Thus, this study aims to answer two research questions, namely (1) how are the contributions and responses of determinants of liquidity, macroeconomic, bond performance, external factors, and internal factors to the 10years GS yield? And, (2) how are the relationship among the inter-determinants within the model?

\section{LITERATURE REVIEW}

The determinant factors in bond yields that define the amount of the Indonesian bond yield prices are interest rate, short-term deposits (i.e., BI certificates), exchange rates, and inflation (Tampubolon, 2007). In particular to the BI certificates, Widajati (2009) found that the inflation and BI interest rates had a simultaneous and significant effect on bond prices, although the correlation between the two variables is 
Jurnal Bisnis dan Manajemen, Volume 22, No. 2, September 2021, p. 127-146

weak. A similar finding also occurred in the research of Wibisono (2010), it is found that inflation, BI rate, output gap, and the exchange rate influenced the changes within the bond yield and concluded that all macroeconomic variables had a positive effect on the Indonesian government bonds. Moreover, Adrian and Muharam (2011) added that the world oil prices significantly influence the determinant model of the government bond yields.

Under the context of the international bond market, Gibson, Hall, and Tavlas (2011) stated that the liquidity factor of capital flow is related to the country's ability to access foreign currencies needed to sell bonds. These factors include the growth of export, the ratio of foreign exchange reserves to GDP that may harm the yield spread, and the debt-service-ratio (DSR) that positively affects bond yield spread. Nonetheless, according to the research of Chee and Fah (2013) in regards to the spread of the United Kingdom (UK) treasury bonds, the shortterm interest rate harms the UK government bond yield while the exchange rate has a significant relationship and positively affects the bond yields. Furthermore, it is also uncovered that the macroeconomic factors (e.g., GDP deflator, international reserves, and stock index) do not affect the UK government bond yield.

The research regarding the GS has also expanded to the countries' macroeconomic conditions. For instance, within the research conducted by Fernandes and Borges (2013), it is found that the fundamental factors of the ratio of debt and government balance are acted as a driver on the GS's return. Moreover, within the context of municipal housing bonds, the aspect of economic and financial indicators can explain the movement of the government debt pricing, and it is also uncovered that the return of the government bonds within the urban construction investment bonds is negatively related to the ratio of issuers leverage with the low quality of issuers due to lack of market participation (Wang \& Yu, 2014).

Within the environment of the domestic government bond, Sihombing, Siregar, Manurung, and Santosa (2013) uncover the fluctuations within the Indonesian government bonds during the period 2003 to 2011 due to it is influenced by the macroeconomic factors (i.e., inflation, industrial production index, money supply, Indonesian rupiah exchange rate, BI rate, and composite stock price index). Moreover, it is also found that the bond yield spread is influenced by the inflation of CPI and BI rate. On the other hand, the CPI and BI rates determinants also influenced the government bond with the five-year tenor (Idham, 2014).

Following the determinants that influenced GS's spread yield, it is also a given that volatility is involved within the equation. According to Muharam (2013), the aspect of domestic interest rate, stock returns, exchange rates, foreign interest rates, world oil price, real sector performance, and variant conditions affect the state debt securities' returns. In contrast, the inflation rate and the real sector's performance do 
Jurnal Bisnis dan Manajemen, Volume 22, No. 2, September 2021, p. 127-146

not affect the government bonds' returns. The DGFRM Ministry of Finance of the Republic of Indonesia (2018) also stated that the determinants of the sovereign credit rating (i.e., Fitch Moody's and $\mathrm{S} \& \mathrm{P}$ ) whose credit rating increased by one had the potential to reduce the yield of new foreign currency of state securities around 75 to 115 basis points (bps). Likewise, as for the Country Risk Classification (CRC), a decrease in one level of CRC has the potential to reduce the cost of foreign loans, especially on the new export credit facilities around 130 to $150 \mathrm{bps}$.

Following the described prior studies on GS yield, it can be concluded that most of them concentrate on the effect generated by changes that occur externally. The country's domestic or internal changes are also indicated to affect the nation's GS yield. Yet, such a view is minimally explored. The uncertainty that exists within a country's internal environment (i.e., country risk), by default, affects GS yield due to its interdependent relationship with a country's macroeconomic well-being (e.g., GDP and exchange rate). Therefore, the literature on GS, especially within the context of Indonesia, can be expanded by thoroughly taking into account the changes that occur within a country's internal and external environment.

\section{METHODS}

\section{Data}

Following the literature review from the previous section regarding the uncovering of GS yield determinants, it has five main components. Namely, liquidity, macroeconomics, Indonesia Sovereign Rating, external factors, and internal factors. Moreover, each of these components has its own determinants. Thus, the determinants in their respective components are used in response to the study's aim are given as follows:

- Liquidity: Foreign exchange reserves.

- Macroeconomics: Inflation, exchange rate, GDP, BI rate and the seven days repo.

- Indonesia Sovereign Rating: Fitch ratings.

- External factors: Oil price and regional bond index.

- Internal factors: Country risk.

Accordingly, each determinant's variables, description, and sources are presented in Table 3. The time horizon of the data spans from 2009M1 to 2018M6. As for the periodical format of the data, it uses the monthly movement for each of the determinants. Particularly for the determinants of GDP, the determinant is available in a quarterly manner. It is interpolated using EViews version 9 to transform its periodical format into monthly movements to maintain consistency of data used in this study.

In regards to the role of the determinants with the GS yield, Equation (1) presents the regression equation of the GS yield spread in response to the specified determinants presented in Table 3. The determinants are acted as independent variables to measure its influence 
Jurnal Bisnis dan Manajemen, Volume 22, No. 2, September 2021, p. 127-146

and relationship in affecting the movement of the 10-years GS yield, which acts as a dependent variable. Hence, concerning this study's aim and nature, the selected determinants are used to uncover its effect and its relationship among the determinants to the 10-years GS yield movement.

Yields

$$
\begin{aligned}
& =\alpha+\beta_{1} \text { BIrt7d } \\
& +\beta_{2} \text { BondValue } \\
& +\beta_{3} \text { CounRisk }+\beta_{4} \text { Exrate } \\
& +\beta_{5} \text { Fitchart }+\beta_{6} \text { GDP } \\
& +\beta_{7} \text { Inflation }+\beta_{8} \text { OilPrice } \\
& +\beta_{9} \text { Reserve }+\beta_{10} \text { Spbidx }
\end{aligned}
$$

\section{Analysis technique}

In conducting the analysis using the specified determinants, the Vector Error Correction Model (VECM) is applied. VECM is based on the premise in which the Vector Auto-Regression (VAR) is endogenous, and each of the variable influence one another (Sims, 1980). Thus, the model's determinants are intended to uncover the variables' interrelations in finding the GS spread yield.
Agung (2013), Rosadi (2011), Vogelvang (2005), and Winarno (2015) revealed one of the approaches to identify the relationships among the non-stationary variables is by implementing an error correction model. Nonetheless, there is also a requirement that has to be fulfilled, which has to be cointegrated within the model. Following this study's nature, there has to be a long-term relationship (equilibrium) that reunites with the economic variables that deviate from the balanced pattern.

Based on the brief explanation of VECM and its requirement in implementing the approach, the VECM can be applied by following the stages explained by Thomsen, Sandager, Logerman, Johanson, and Andersen (2013). As for the approach to meet the model requirement, the cointegration test is applied using the Johansen cointegration test (Gonzalo, 1994). The stages of VECM are given as follows.

The first stage of VECM is to determine whether the data is stationary or not. The stationary test is conducted by applying the

Table 3. The descriptions and sources of the determinants

\begin{tabular}{ccl}
\hline Determinant & Description & \multicolumn{1}{c}{ Data Source } \\
\hline Yields & GS yield spread (10Y) & Ministry of Finance DGFRM, Republic of Indonesia \\
BIrt7dr & BI rate / 7 days repo & Bank Indonesia \\
BondValue & Outstanding tradable bond & Ministry of Finance DGFRM, Republic of Indonesia \\
CounRisk & CRC & CRC of officially supported export credits by Organisation \\
& for Economic Co-operation and Development (OECD) \\
Exrate & Exchange rate & Bank Indonesia \\
Fitchart & Fitch Rating & Sovereign Rating \\
GDP & GDP & Central Bureau of Statistics \\
Inflation & CPI & Central Bureau of Statistics \\
OilPrice & Oil price US/Barrel & World Bank \\
Reserve & Reserve assets & Bank Indonesia \\
Spbidx & Regional bond index & S\&P Pan Asia Gov.Bond Index \\
\hline
\end{tabular}


Jurnal Bisnis dan Manajemen, Volume 22, No. 2, September 2021, p. 127-146

Augmented-Dickey Fuller (ADF) test with the Schwarz Information Criterion (SIC). Moreover, the stationary test is also performed at the differentiation level by subtracting the data at time $t$ with its previous value. If the data is found to be stationary, it can be considered that the data used in this study have been stationary in the first degree. On the other hand, if the data is not stationary, the second stage of VECM can not be implemented.

The second stage of VECM is to determine if the data used in this study has a cointegration relationship. The Johansen cointegration test is applied to determine such a relationship as recommended by Gonzalo (1994). In other words, the Johansen cointegration test is applied to determine if the specified determinants are not deviating from the equilibrium in the long term. Furthermore, it is also used to see the degree of sensitiveness of the determinants in the model.

The third stage of VECM is to determine the model's optimal lag in response to its determinants. The criteria used in determining the optimal lags are Final Prediction Error (FPE), Likelihood Ratio (LR), Akaike Information Criterion (AIC), SIC, and Hannan-Quin Criterion (HQ). After the optimal lag is determined, it proceeds to a deterministic assumption test to form cointegration equations based on the SIC criteria. It is used to uncover the number of cointegration relationships among the variables under the Trace Statistics and Max Eigen Value method. As for the Johansen cointegration test, it is done by determining the $\lambda$ trace and $\lambda$ max.
The null hypothesis's determination is expressed in $\lambda$ max in the $r$ cointegration vector, and as for the alternative hypothesis, it is expressed in $r+1$ cointegration vector. In regards to the value of $\lambda$ trace and $\lambda \max$, if the value is found to be higher than the critical value of $5 \%$, it can be stated that the time series data used in the model are cointegrated. After the time series data are found to be cointegrated in the model, VECM is applied to uncover the short-term relationship among the variables to explain each variable's short-term behavior to its long-term behavior (due to permanent shock).

Before entering the VECM estimate stage, the Error Correction Term (ECT) is used to determine the relationships among the variables. The type of the relationship is given as follows: (1) a short-term relationship occurs when the ECT is not significant, (2) a long-term relationship occurs when the ECT coefficient is negative and significant, and (3) an explosive relationship occurs when the ECT coefficient is positive and significant. During this phase, the VECM has been formed.

Lastly, at the VECM estimate stage, this stage is focused on uncovering the effects of the determinants to the model, the Impulse Response Function (IRF) and the Forecast Decomposition of Variance Error (FDVE) are used. The IRF is used to analyze the endogenous variables in the current and the future period in terms of their response to the shock that occurs in the current interruption variables. Meanwhile, the FDVE is used to analyze the contribution of each variable's 
Jurnal Bisnis dan Manajemen, Volume 22, No. 2, September 2021, p. 127-146

variants in regards to the changes in the particular variable within the VECM.

\section{RESULTS AND DISCUSSIONS}

Following the VECM stages previously explained in the previous section, this section consists of two sub-sections. The first sub-section presents the determinants in terms of their validity explained in the order of stages of the stationary test, cointegration test, and optimal lag test. As for the second sub-section, the effects of the determinants on the GS yield are presented along with its relationship, particularly from the findings obtained from the stage of the VECM estimate.

\section{Determinants assessments results}

In the first stage of the VECM, the stationary test result for each of the determinants using the ADF test is presented in Table 4. As shown in Table 4, it is found that the GS yield and bond value are stationary at the level test. These two determinants have the ADF test statistics higher than the critical values at the levels of $1 \%, 5 \%$, and $10 \%$. Moreover, eight determinants are stationary at the first differentiation. These eight determinants are (1) BI rate / seven days repo, (2) country risk, (3) exchange rate, (4) Fitch Rating, (5) inflation, (6) oil price, (7) reserve, and (8) regional bond index. Particularly for GDP, the stationary test occurs on the second differentiation. Hence, all determinants used in this study are stationary.
Table 4. Stationary Test with ADF Test

\begin{tabular}{|c|c|c|c|}
\hline \multicolumn{2}{|c|}{$\begin{array}{c}\text { Augmented Dickey- } \\
\text { Fuller test } \\
\text { statistic }\end{array}$} & t-Statistic & Prob.* \\
\hline \multicolumn{2}{|l|}{ D(YIELDS) } & -4.782228 & 0.0009 \\
\hline \multirow[t]{3}{*}{$\begin{array}{l}\text { Test critical } \\
\text { values: }\end{array}$} & $1 \%$ level & -4.042042 & \\
\hline & $5 \%$ level & -3.450436 & \\
\hline & $10 \%$ level & -3.150549 & \\
\hline \multicolumn{2}{|l|}{ D(BIRT7DR) } & -5.575131 & 0.0000 \\
\hline \multirow[t]{3}{*}{$\begin{array}{l}\text { Test critical } \\
\text { values: }\end{array}$} & $1 \%$ level & -4.042042 & \\
\hline & $5 \%$ level & -3.450436 & \\
\hline & $10 \%$ level & -3.150549 & \\
\hline \multicolumn{2}{|c|}{ BONDVALUE } & -6.164161 & 0.0000 \\
\hline \multirow[t]{3}{*}{$\begin{array}{l}\text { Test critical } \\
\text { values: }\end{array}$} & $1 \%$ level & -4.041280 & \\
\hline & $5 \%$ level & -3.450073 & \\
\hline & $10 \%$ level & -3.150336 & \\
\hline \multicolumn{2}{|c|}{$\mathrm{D}(\mathrm{COUNRISK})$} & -10.80510 & 0.0000 \\
\hline \multirow[t]{3}{*}{$\begin{array}{l}\text { Test critical } \\
\text { values: }\end{array}$} & $1 \%$ level & -4.042042 & \\
\hline & $5 \%$ level & -3.450436 & \\
\hline & $10 \%$ level & -3.150549 & \\
\hline \multicolumn{2}{|l|}{ D(EXRATE) } & -10.87213 & 0.0000 \\
\hline \multirow[t]{3}{*}{$\begin{array}{l}\text { Test critical } \\
\text { values: }\end{array}$} & $1 \%$ level & -4.042042 & \\
\hline & $5 \%$ level & -3.450436 & \\
\hline & $10 \%$ level & -3.150549 & \\
\hline \multicolumn{2}{|c|}{$\mathrm{D}(\mathrm{FITCHRAT})$} & -10.54686 & 0.0000 \\
\hline \multirow[t]{3}{*}{$\begin{array}{l}\text { Test critical } \\
\text { values: }\end{array}$} & $1 \%$ level & -4.042042 & \\
\hline & $5 \%$ level & -3.450436 & \\
\hline & $10 \%$ level & -3.150549 & \\
\hline \multicolumn{2}{|l|}{$\mathrm{D}(\mathrm{GDP}, 2)$} & -9.293230 & 0.0000 \\
\hline \multirow[t]{3}{*}{$\begin{array}{l}\text { Test critical } \\
\text { values: }\end{array}$} & $1 \%$ level & -4.044415 & \\
\hline & $5 \%$ level & -3.451568 & \\
\hline & $10 \%$ level & -3.151211 & \\
\hline \multicolumn{2}{|l|}{ D(INFLASI) } & -7.304519 & 0.0000 \\
\hline \multirow[t]{3}{*}{$\begin{array}{l}\text { Test critical } \\
\text { values: }\end{array}$} & $1 \%$ level & -4.042819 & \\
\hline & $5 \%$ level & -3.450807 & \\
\hline & $10 \%$ level & -3.150766 & \\
\hline \multicolumn{2}{|l|}{ D(OILPRICE) } & -8.870228 & 0.0000 \\
\hline \multirow[t]{3}{*}{$\begin{array}{l}\text { Test critical } \\
\text { values: }\end{array}$} & $1 \%$ level & -4.042042 & \\
\hline & $5 \%$ level & -3.450436 & \\
\hline & $10 \%$ level & -3.150549 & \\
\hline \multicolumn{2}{|c|}{$\mathrm{D}(\mathrm{RESERVE})$} & -8.909011 & 0.0000 \\
\hline \multirow{2}{*}{$\begin{array}{l}\text { Test critical } \\
\text { values: }\end{array}$} & $1 \%$ level & -4.042042 & \\
\hline & $5 \%$ level & -3.450436 & \\
\hline
\end{tabular}


Jurnal Bisnis dan Manajemen, Volume 22, No. 2, September 2021, p. 127-146

\begin{tabular}{rlll}
\hline $\begin{array}{c}\text { Augmented Dickey- } \\
\text { Fuller test } \\
\text { statistic }\end{array}$ & t-Statistic & Prob.* \\
\hline & $10 \%$ level & -3.150549 & \\
\hline D(SPBIDX) & & -9.614906 & 0.0000 \\
\hline Test critical & & -4.042042 & \\
values: & $1 \%$ level & -3.450436 & \\
& 5\% level & -3.150549 & \\
& $10 \%$ level & & \\
\hline
\end{tabular}

*MacKinnon (1996) one-sided p-values.

Source: Output EViews version 9, 2018, processed.

At the second stage of VECM, regarding the cointegration test with the Johansen cointegration test, it is determined based on the Max Eigenvalue test. Six determinants had cointegration with yields. These six determinants are BI rate / seven days repo, bond value, exchange rate, Fitch Rating, country risk, and regional bond index. The determination of these six determinants is based on the cointegration hypothesis, in which the hypothesis is rejected if the probability is higher than 5\%. Consequently, the hypothesized values are accepted based on the unrestricted cointegration rank test that includes the maximum eigenvalue and trace. The snapshot results of the cointegration test of all determinants are presented in Table 5.

Table 5. Cointegration Test Result

\begin{tabular}{lcccc}
\hline $\begin{array}{l}\text { Hypothesized } \\
\text { No. of CE(s) }\end{array}$ & Eigenvalue & $\begin{array}{c}\text { Trace } \\
\text { Statistic }\end{array}$ & $\begin{array}{c}\mathbf{0 . 0 5} \\
\text { Critical Value }\end{array}$ & Prob.** \\
\hline None & 0.696166 & 534.6542 & 306.8944 & 0.0000 \\
At most 1* & 0.552915 & 404.8054 & 259.0294 & 0.0000 \\
At most 2* & 0.512517 & 317.0596 & 215.1232 & 0.0000 \\
At most 3* & 0.419432 & 238.7432 & 175.1715 & 0.0000 \\
At most 4* & 0.378289 & 179.4747 & 139.2753 & 0.0000 \\
At most 5* & 0.359414 & 127.6691 & 107.3466 & 0.0012 \\
At most 6 & 0.235681 & 79.12357 & 79.34145 & 0.0519 \\
At most 7 & 0.182215 & 49.82769 & 55.24578 & 0.1378 \\
At most 8 & 0.122307 & 27.90170 & 35.01090 & 0.2344 \\
At most 9 & 0.077736 & 13.68174 & 18.39771 & 0.2017 \\
At most 10* & 0.043617 & 4.861018 & 3.841466 & 0.0275 \\
\hline
\end{tabular}

Trace test indicates six cointegrating eqn(s) at the 0.05 level.

* denotes rejection of the hypothesis at the 0.05 level

**MacKinnon, Haug, and Michelis (1999) p-values

Unrestricted Cointegration Rank Test (Maximum Eigenvalue)

\begin{tabular}{|c|c|c|c|c|}
\hline $\begin{array}{l}\text { Hypothesized } \\
\text { No. of CE(s) }\end{array}$ & Eigenvalue & $\begin{array}{c}\text { Max-Eigen } \\
\text { Statistic }\end{array}$ & $\begin{array}{c}0.05 \\
\text { Critical Value }\end{array}$ & Prob.** \\
\hline None $*$ & 0.696166 & 129.8487 & 73.94036 & 0.0000 \\
\hline At most $1 *$ & 0.552915 & 87.74581 & 67.91026 & 0.0003 \\
\hline At most $2 *$ & 0.512517 & 78.31646 & 61.80550 & 0.0006 \\
\hline At most $3 *$ & 0.419432 & 59.26850 & 55.72819 & 0.0213 \\
\hline At most $4 *$ & 0.378289 & 51.80554 & 49.58633 & 0.0290 \\
\hline At most $5 *$ & 0.359414 & 48.54556 & 43.41977 & 0.0128 \\
\hline At most 6 & 0.235681 & 29.29588 & 37.16359 & 0.3011 \\
\hline At most 7 & 0.182215 & 21.92599 & 30.81507 & 0.4031 \\
\hline At most 8 & 0.122307 & 14.21996 & 24.25202 & 0.5674 \\
\hline At most 9 & 0.077736 & 8.820721 & 17.14769 & 0.5143 \\
\hline At most $10 *$ & 0.043617 & 4.861018 & 3.841466 & 0.0275 \\
\hline
\end{tabular}

Max-eigenvalue test indicates 6 cointegrating eqn(s) at the 0.05 level

* denotes rejection of the hypothesis at the 0.05 level **MacKinnon, Haug, and Michelis (1999) p-values

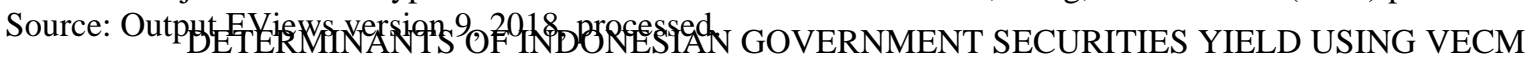

(Batara Maju Simatupang) 
Jurnal Bisnis dan Manajemen, Volume 22, No. 2, September 2021, p. 127-146

Table 6. Optimal Lag Test Result

\begin{tabular}{ccccccc}
\hline Lag & LogL & LR & FPE & AIC & SC & HQ \\
\hline 0 & -4426.174 & NA & $6.34 \mathrm{e}+22$ & 83.72026 & 83.99665 & 83.83228 \\
1 & -3198.975 & 2176.541 & $5.52 \mathrm{e}+13$ & 62.84859 & $66.16532^{*}$ & 64.19288 \\
2 & -3064.071 & 211.2650 & $4.54 \mathrm{e}+13$ & 62.58624 & 68.94332 & 65.16280 \\
3 & -2976.613 & 118.8112 & $1.02 \mathrm{e}+14$ & 63.21911 & 72.61652 & 67.02793 \\
4 & -2893.237 & 95.96108 & $3.03 \mathrm{e}+14$ & 63.92899 & 76.36675 & 68.97008 \\
5 & -2738.065 & 146.3880 & $3.13 \mathrm{e}+14$ & 63.28425 & 78.76235 & 69.55761 \\
6 & -2491.677 & 181.3047 & $9.48 \mathrm{e}+13$ & 60.91843 & 79.43687 & 68.42406 \\
7 & -2195.133 & 156.6645 & $2.66 \mathrm{e}+13$ & 57.60629 & 79.16507 & 66.34418 \\
8 & -1678.700 & $165.6483^{*}$ & $7.14 \mathrm{e}+11^{*}$ & $50.14529^{*}$ & 74.74441 & $60.11544^{*}$ \\
\hline
\end{tabular}

* indicates lag order selected by the criterion

LR: sequential modified LR test statistic (each test at 5\% level)

FPE: Final prediction error

AIC: Akaike information criterion

SIC: Schwarz information criterion

Source: Output EViews Ver. 9, processed.

As shown in Table 5, the cointegrated determinants of the VECM with the dependent variable of GS yield occur in the determinants of $\mathrm{BI}$ rate / seven days repo (0.0000), bond value (0.0000), country risk (0.0000), the exchange rate (0.0000), Fitch Rating (0.0012), and regional bond index (0.0275). Meanwhile, according to the unrestricted cointegrated rank test (maximum eigenvalue), the cointegration occurs in the determinant of BI rate / seven days repo (0.0003), bond value (0.0006), country risk (0.0213), the exchange rate (0.0290), Fitch Rating (0.0128), and regional bond index (0.0275). Thus, it is found that the determinants that are cointegrated with the GS yield are the BI rate / seven days repo, outstanding tradable bond, and country risk are based on the supported export credit, exchange rates, fitch rating, and regional bond index.

At the third stage of VECM in regards to the determination of optimal lag, it is found that the optimal lag for the determinants in the VECM is at lag 8. The results of the optimal lag are presented in Table 6. The LR, FPE, AIC, SIC, and HQ criteria of the model are less than $5 \%$ in terms of their confidence level. Implementing an optimal lag test aims to eliminate the autocorrelation problem in the VAR system, specifically for the VAR stability analysis. Even though the optimal lag's determination is at lag 8 , the VECM is differentiated by one stage. Hence, the lag level used for the VECM estimation is lag 7 .

In terms of the determinants' VAR stability test, it is implemented to check if the form of the root of the model is characteristically polynomial to all determinants. It is applied by multiplying the number of lags of each VAR. The results of the VAR stability test are presented in Table 7. The results show that all the roots have a modulus smaller than one. Therefore, the IRF and FDVE of the model have been stable with a modulus range of less than one. 
Jurnal Bisnis dan Manajemen, Volume 22, No. 2, September 2021, p. 127-146

Table 7. VAR Stability Test

\begin{tabular}{ll}
\hline \multicolumn{1}{c}{ Root } & Modulus \\
\hline 0.989971 & 0.989971 \\
$0.941816-0.051242 \mathrm{i}$ & 0.943208 \\
$0.941816+0.051242 \mathrm{i}$ & 0.943208 \\
0.852186 & 0.852186 \\
0.720068 & 0.720068 \\
$0.632780-0.228234 \mathrm{i}$ & 0.672683 \\
$0.632780+0.228234 \mathrm{i}$ & 0.672683 \\
$0.140739-0.234200 \mathrm{i}$ & 0.273234 \\
$0.140739+0.234200 \mathrm{i}$ & 0.273234 \\
$-0.112470-0.184263 \mathrm{i}$ & 0.215876 \\
$-0.112470+0.184263 \mathrm{i}$ & 0.215876 \\
-0.206836 & 0.206836 \\
0.145653 & 0.145653 \\
0.035184 & 0.035184 \\
\hline
\end{tabular}

No root lies outside the unit circle.

VAR satisfies the stability condition.

Source: Output EViews Ver. 9, processed.

Through the VECM estimation, the determinant of GS yield act as a dependent variable, while the rest of the determinants act as independent variables. The VECM estimation results are the basis for analyzing the short-term and long-term effects of the independent variables on the dependent variables. The VECM estimation is presented in Table 8.

Based on the results in Table 8 , it is found that the amount of adjustment from the short-tolong term is $-0.0255 \%$, which shows that there is a short pause in adjusting for changes in the determinants that exist in the VECM, and there are several independent variables that affected GS yield. The effects of the independent variables on the GS yield are given as follows:

- BI rate / seven days repo has positive effects, which indicates that if there is an increase in tradable GS, then BI rate / seven days repo will increase by $0.787 \%$.
- Outstanding tradable GS has a negative effect with the value of $-0.0591 \%$, which will decrease the growth of the GS yield.

- Country risk has a positive effect on the GS yield, which indicates that an increase in tradable GS yield is also accompanied by an increase in country risk by $6.3501 \%$.

- The determinant of the exchange rate has a negative effect on the GS yield by $0.0022 \%$.

- Fitch Rating has a positive effect, indicating that an increase in tradable GS will also be accompanied by the increase of Fitch Rating by $3.0298 \%$.

- The determinant of the regional bond index positively affects the GS yield by $1.4856 \%$.

Table 8. VECM Estimation Results

\begin{tabular}{lll}
\hline $\begin{array}{c}\text { Standard errors in } \\
\text { ( ) \& t-statistics in } \\
\text { [ ] }\end{array}$ & CointEq1 & T Statistic \\
\hline YIELDS(-1) & 1.000000 & \\
& & \\
BIRT7DR(-1) & 0.787000 & [ 1.86096] \\
& $(0.42290)$ & \\
BONDVALUE(-1) & -0.059144 & [-4.27066] \\
& $(0.01385)$ & \\
COUNRISK(-1) & 6.350170 & [ 3.02322] \\
& $(2.10046)$ & \\
EXRATE(-1) & -0.002228 & [-3.47863] \\
& $(0.00064)$ & \\
FITCHRAT(-1) & 3.029872 & [ 1.27956] \\
& $(2.36790)$ & \\
SPBIDX(-1) & 1.485611 & [ 5.54419] \\
& $(0.26796)$ & \\
C & -162.3117 & \\
\hline Sources: Output EViews Ver. 9, processed.
\end{tabular}

Sources: Output EViews Ver. 9, processed.

Regarding the impact of a shock of one determinant to another in short-term and longterm effects, the indicator of IRF and FDVE tests are used. In terms of the IRF test results, it is found that the determinants are responded to the 
Jurnal Bisnis dan Manajemen, Volume 22, No. 2, September 2021, p. 127-146

determinants of yield, which is marked by its fall in the second month. From that moment on, it is found that the yield determinant is slowly increasing to the seventh month. As for the other determinants, it is given as follows:

- The determinant of BI rate / seven days repo response to the other determinants gradually increases until the fourth month and moves stably for the following months.

- The response of outstanding tradable GS to the other determinants is stable until the fourth month, and then it is beginning to increase in the following months slowly.

- The country risk response on the supports of credit was initially high but steadily decreasing since the second month.

- The determinants of the exchange rate response to the other determinants were relatively slow and stable at the beginning of the period. However, in the fourth month, it is beginning to increase and showing a positive trend slowly.

- The Fitch Rating determinant's initial response was good, and yet, in the seventh month, it is dropped dramatically.

- The determinants of regional bond index response to the other determinant are high until it dropped in the fifth month. Since then, it becomes stable once more.

Following the IRF test results, the complete test result of IRF and its movements are presented in Table 9 and Figure 1, respectively.
As for the FDVE results of the determinants, it is found that the contribution of the independent variables to the dependent variable in the model is relatively similar in the early months. Except for the determinant of the exchange rate, which is found to have a relatively lower contribution level in the initial months and remains lower than the rest of the determinants throughout the period. The FDVE results test of the model's determinants and its movement are presented in Table 10 and Figure 2, respectively. Based on the FDVE results, the contributions of all determinants to the determinant of yield in the VECM that are ranked from the highest contribution to the lowest within the seven months are given as follows:

- Country risk: 99.69\%, 97.97\%, 96.28\%, $92.76 \%, 90.42 \%, 88.89 \%$, and $87.58 \%$.

- Fitch Rating: 98.76\%, 93.06\%, 91.66\%, $91.37 \%, 90.46 \%, 89.98 \%$, and $81.95 \%$.

- BI rate / 7 days repo: 98.05\%, 95.68\%, $94.35 \%, 94.74 \%, 95.45 \%, 94.25 \%$, and $93.36 \%$.

- Outstanding tradable GS: $97.71 \%, 91.35 \%$, $76.71 \%, 74.26 \%, 68.67 \%, 66.41 \%$, and $64.74 \%$.

- Regional bond index: 94.49\%, 94.08\%, $92.60 \%, 91.89 \%, 86.14 \%, 82.77 \%$, and $77.84 \%$.

- Exchange rate: $84.28 \%, 80.60 \%, 74.58 \%$, $64.80 \%, 55.64 \%, 49.55 \%$, and $44.92 \%$. 
Jurnal Bisnis dan Manajemen, Volume 22, No. 2, September 2021, p. 127-146

Table 9. Determinants' IRF Test Results

\begin{tabular}{|c|c|c|c|c|c|c|}
\hline Period & YIELDS & BIRT7DR & $\begin{array}{c}\text { Response of YIELDS: } \\
\text { BONDVALUE }\end{array}$ & COUNRISK & EXRATE & FITCHRAT \\
\hline 1 & 0.403327 & 0.000000 & 0.000000 & 0.000000 & 0.000000 & 0.000000 \\
\hline 2 & 0.121194 & 0.077792 & 0.003102 & 0.047047 & 0.010365 & 0.027804 \\
\hline 3 & 0.176401 & 0.107350 & 0.065175 & 0.021253 & 0.026725 & 0.023039 \\
\hline 4 & 0.163427 & 0.127665 & 0.068386 & 0.054351 & 0.068904 & 0.016725 \\
\hline 5 & 0.224070 & -0.005003 & -0.023565 & -0.019294 & -0.003290 & 0.005756 \\
\hline 6 & 0.229734 & 0.019054 & 0.028132 & -0.026445 & -0.004890 & 0.050713 \\
\hline 7 & 0.200633 & 0.075481 & 0.094588 & -0.017927 & -0.002927 & 0.055471 \\
\hline \multicolumn{7}{|c|}{ Response of BIRT7DR: } \\
\hline 1 & -0.031414 & 0.222826 & 0.000000 & 0.000000 & 0.000000 & 0.000000 \\
\hline 2 & -0.036745 & 0.336110 & 0.043231 & -0.018342 & -0.024592 & 0.007193 \\
\hline 3 & 0.001220 & 0.446990 & 0.087166 & -0.036717 & -0.065897 & -0.021581 \\
\hline 4 & 0.004473 & 0.543490 & 0.072697 & -0.050319 & -0.074155 & -0.037860 \\
\hline 5 & 0.044792 & 0.552766 & -0.022223 & -0.038069 & -0.045576 & -0.048698 \\
\hline 6 & 0.086573 & 0.530008 & -0.080996 & -0.033862 & -0.075076 & -0.056526 \\
\hline 7 & 0.106883 & 0.524151 & -0.059243 & -0.024070 & -0.076677 & -0.055706 \\
\hline
\end{tabular}

\begin{tabular}{|c|c|c|c|c|c|c|}
\hline \multicolumn{7}{|c|}{ Response of BONDVALUE: } \\
\hline Period & YIELDS & BIRT7DR & BONDVALUE & COUNRISK & EXRATE & FITCHRAT \\
\hline 1 & 7.726350 & 3.843943 & 56.45970 & 0.000000 & 0.000000 & 0.000000 \\
\hline 2 & 4.849503 & 5.058939 & 30.09089 & 3.956285 & -14.14915 & -4.674113 \\
\hline 3 & -6.349019 & 27.39530 & 31.49062 & 3.029269 & -13.48262 & -3.146156 \\
\hline 4 & 1.670181 & 11.85110 & -2.662115 & 4.865834 & -6.072791 & -4.001415 \\
\hline 5 & 0.920378 & 20.81244 & 11.68647 & 0.856601 & -8.251217 & -3.119694 \\
\hline 6 & 1.290826 & 15.22914 & 5.801608 & 5.674927 & -0.275159 & -2.421454 \\
\hline 7 & 4.256495 & 11.92962 & 12.94734 & 0.972707 & -7.231835 & -3.269630 \\
\hline \multicolumn{7}{|c|}{ Response of COUNRISK: } \\
\hline Period & YIELDS & BIRT7DR & BONDVALUE & COUNRISK & EXRATE & FITCHRAT \\
\hline 1 & 0.007974 & -0.001860 & -0.004564 & 0.170686 & 0.000000 & 0.000000 \\
\hline 2 & 0.018733 & -0.007807 & 0.006465 & 0.168324 & 0.023601 & -0.005628 \\
\hline 3 & 0.029346 & -0.011069 & 0.002622 & 0.155350 & 0.019643 & -0.012538 \\
\hline 4 & 0.057518 & -0.012736 & -0.013215 & 0.152727 & 0.034156 & -0.010945 \\
\hline 5 & 0.064313 & 0.009765 & 0.008147 & 0.146921 & 0.025268 & -0.011690 \\
\hline 6 & 0.062041 & 0.007790 & -0.004639 & 0.147742 & 0.033332 & -0.009616 \\
\hline 7 & 0.065421 & 0.013117 & 0.010367 & 0.136419 & 0.019815 & -0.007889 \\
\hline \multicolumn{7}{|c|}{ Response of EXRATE: } \\
\hline Period & YIELDS & BIRT7DR & BONDVALUE & COUNRISK & EXRATE & FITCHRAT \\
\hline 1 & -10.10387 & 79.21894 & -40.90182 & 20.56357 & 213.1606 & 0.000000 \\
\hline 2 & -3.899240 & 26.30719 & -81.72045 & 12.21757 & 153.0546 & -23.60449 \\
\hline 3 & 55.16095 & 63.66686 & -51.66621 & 26.52443 & 114.6422 & -23.15764 \\
\hline 4 & 39.88824 & 21.73724 & -125.2120 & 63.29371 & 114.5461 & -29.03481 \\
\hline 5 & 52.76694 & 19.92248 & -170.1766 & 73.73076 & 166.9012 & -23.28020 \\
\hline 6 & 58.41260 & 35.95187 & -138.2123 & 92.71253 & 123.0723 & -37.22108 \\
\hline 7 & 50.96363 & 37.67792 & -141.4757 & 106.5453 & 106.2546 & -42.60274 \\
\hline
\end{tabular}

$\begin{array}{lllll}\text { Period YIELDS BIRT7DR BONDVALUE COUNRISK } & \text { EXRATE } & \text { FITCHRAT }\end{array}$


Jurnal Bisnis dan Manajemen, Volume 22, No. 2, September 2021, p. 127-146

\begin{tabular}{ccccccc}
1 & 0.004312 & -0.004534 & 0.000546 & 0.002814 & -0.006481 & 0.084619 \\
2 & 0.024319 & 0.007156 & -0.004546 & 0.002471 & -0.011650 & 0.085774 \\
3 & 0.020074 & 0.000832 & -0.010361 & -0.000131 & -0.010651 & 0.086033 \\
4 & 0.018079 & 0.007025 & -0.009279 & -0.000644 & -0.006638 & 0.087367 \\
5 & 0.014354 & 0.006012 & -0.014158 & 0.003663 & -0.003763 & 0.088398 \\
6 & 0.015215 & -0.002947 & -0.013398 & 0.002374 & -0.008188 & 0.089237 \\
7 & 0.006862 & 0.005730 & -0.012291 & -0.080502 & -0.003868 & 0.092862 \\
\hline & & & Response of SPBIDX: & & & EXRATE \\
Period & YIELDS & BIRT7DR & BONDVALUE & COUNRISK & EXRAT \\
1 & 0.081627 & -0.117226 & 0.132738 & -0.009847 & -0.074603 & -0.144282 \\
2 & 0.015348 & -0.163624 & 0.139860 & -0.089547 & 0.154005 & -0.075574 \\
3 & -0.151038 & -0.145206 & -0.095596 & 0.075777 & 0.263392 & 0.009331 \\
4 & -0.266512 & 0.074755 & 0.048529 & 0.027505 & 0.164351 & 0.020952 \\
5 & -0.410410 & 0.100990 & 0.310448 & -0.288556 & 0.025026 & 0.030902 \\
6 & -0.345762 & -0.048629 & 0.199595 & -0.342081 & 0.106573 & 0.115235 \\
7 & -0.439744 & 0.125717 & 0.065682 & -0.589051 & 0.157775 & 0.033938 \\
\hline
\end{tabular}

Cholesky Ordering: YIELDS BIRT7DR BONDVALUE COUNRISK EXRATE FITCHRAT SPBIDX

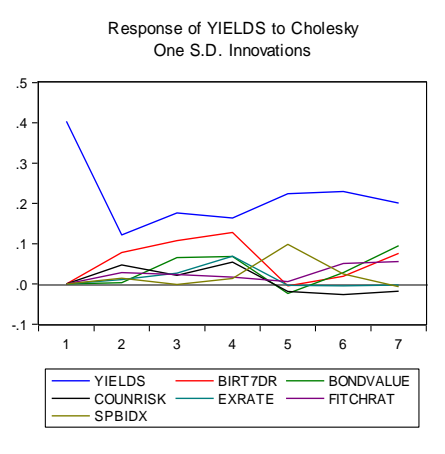

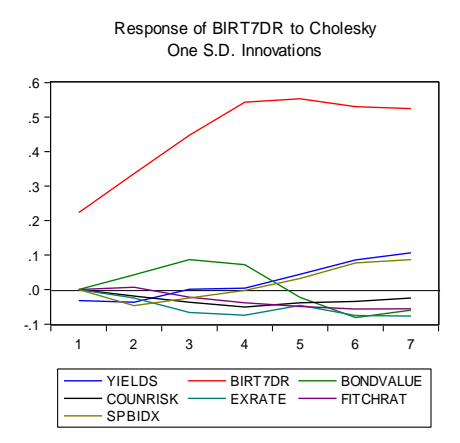
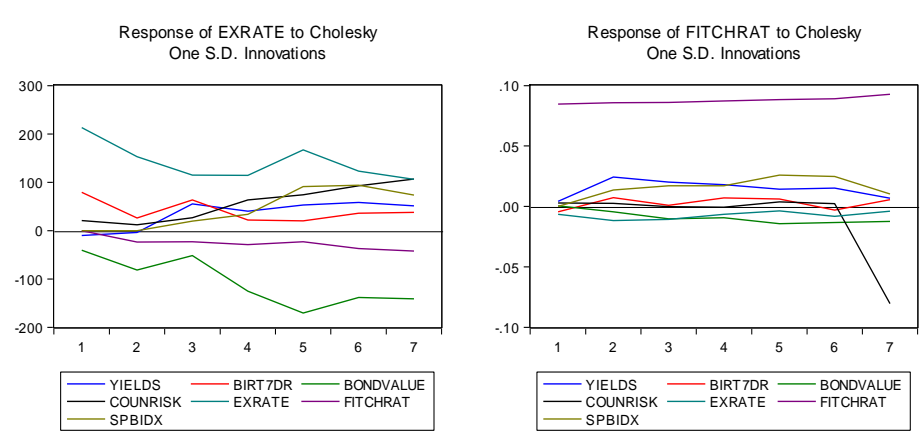
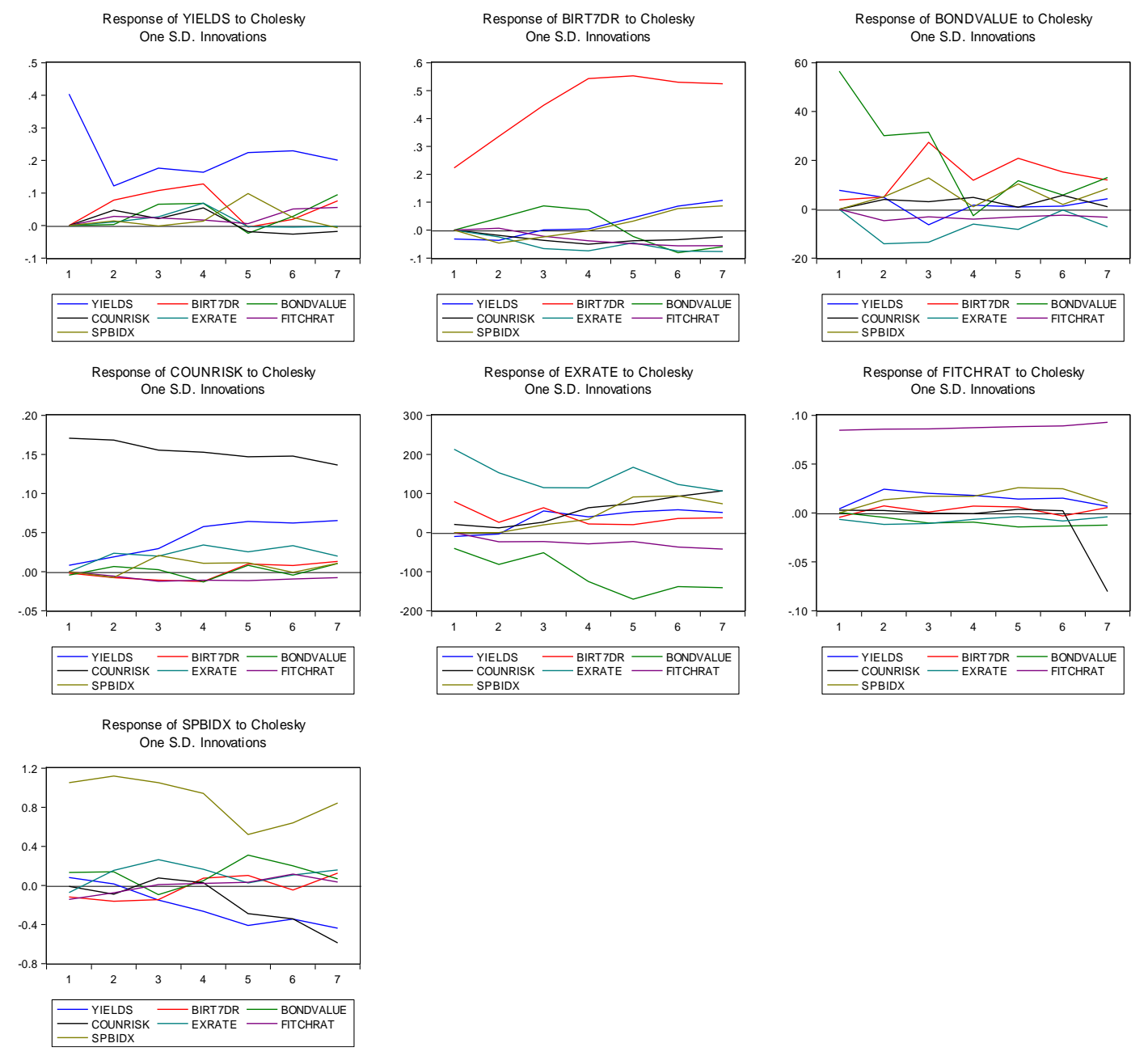

esponse of SPBIDX to Cholesky

Figure 1. Determinants' IRF Movements 
Jurnal Bisnis dan Manajemen, Volume 22, No. 2, September 2021, p. 127-146

Table 10. FDVE Test Results

Variance Decomposition of YIELDS:

\begin{tabular}{ccccccccc} 
Period & S.E. & YIELDS & BIRT7DR & BONDVALUE & COUNRISK & EXRATE & FITCHRAT & SPBIDX \\
\hline 1 & 0.403327 & 100.0000 & 0.000000 & 0.000000 & 0.000000 & 0.000000 & 0.000000 & 0.000000 \\
2 & 0.432093 & 94.99543 & 3.241237 & 0.005153 & 1.185513 & 0.057537 & 0.414066 & 0.101068 \\
3 & 0.485069 & 88.60398 & 7.469656 & 1.809433 & 1.132670 & 0.349211 & 0.554161 & 0.080892 \\
4 & 0.539567 & 80.78318 & 11.63523 & 3.068724 & 1.930084 & 1.913012 & 0.543957 & 0.125813 \\
5 & 0.593284 & 81.08089 & 9.630763 & 2.695944 & 1.702154 & 1.585352 & 0.459326 & 2.845573 \\
6 & 0.640179 & 82.51512 & 8.360065 & 2.508546 & 1.632551 & 1.367430 & 1.022030 & 2.594259 \\
7 & 0.684242 & 80.82780 & 8.534923 & 4.106837 & 1.497702 & 1.198817 & 1.551859 & 2.282062 \\
\hline
\end{tabular}

\begin{tabular}{|c|c|c|c|c|c|c|c|c|}
\hline \multirow[b]{2}{*}{ Period } & \multirow[b]{2}{*}{ S.E. } & \multirow[b]{2}{*}{ YIELDS } & \multicolumn{3}{|c|}{ Variance Decomposition of BIRT7DR: } & \multirow[b]{2}{*}{ EXRATE } & \multirow[b]{2}{*}{ FITCHRAT } & \multirow[b]{2}{*}{ SPBIDX } \\
\hline & & & BIRT7DR & BONDVALUE & COUNRISK & & & \\
\hline 1 & 0.225030 & 1.948803 & 98.05120 & 0.000000 & 0.000000 & 0.000000 & 0.000000 & 0.000000 \\
\hline 2 & 0.412265 & 1.375037 & 95.68056 & 1.099615 & 0.197952 & 0.355826 & 0.030440 & 1.260573 \\
\hline 3 & 0.619770 & 0.608812 & 94.35238 & 2.464583 & 0.438561 & 1.287959 & 0.134716 & 0.712984 \\
\hline 4 & 0.833229 & 0.339716 & 94.74741 & 2.124781 & 0.607336 & 1.504638 & 0.280995 & 0.395126 \\
\hline 5 & 1.004614 & 0.432484 & 95.45248 & 1.510586 & 0.561386 & 1.240868 & 0.428270 & 0.373928 \\
\hline 6 & 1.148982 & 0.898356 & 94.25089 & 1.651767 & 0.516030 & 1.375577 & 0.569442 & 0.737934 \\
\hline 7 & 1.275548 & 1.431062 & 93.36043 & 1.555949 & 0.454312 & 1.477491 & 0.652769 & 1.067988 \\
\hline
\end{tabular}

\begin{tabular}{|c|c|c|c|c|c|c|c|c|}
\hline \multirow[b]{2}{*}{ Period } & \multirow[b]{2}{*}{ S.E. } & \multirow[b]{2}{*}{ YIELDS } & \multicolumn{4}{|c|}{ Variance Decomposition of BONDVALUE: } & \multirow[b]{2}{*}{ FITCHRAT } & \multirow[b]{2}{*}{ SPBIDX } \\
\hline & & & BIRT7DR & BONDVALUE & COUNRISK & EXRATE & & \\
\hline 1 & 57.11541 & 1.829962 & 0.452947 & 97.71709 & 0.000000 & 0.000000 & 0.000000 & 0.000000 \\
\hline 2 & 66.93644 & 1.857257 & 0.900991 & 91.35524 & 0.349341 & 4.468233 & 0.487611 & 0.581331 \\
\hline 3 & 81.41612 & 1.863508 & 11.93122 & 76.71046 & 0.374569 & 5.762611 & 0.478920 & 2.878707 \\
\hline 4 & 82.80368 & 1.842261 & 13.58312 & 74.26446 & 0.707436 & 6.108970 & 0.696526 & 2.797221 \\
\hline 5 & 87.25651 & 1.670158 & 17.92135 & 68.67200 & 0.646713 & 6.395591 & 0.755079 & 3.939113 \\
\hline 6 & 89.00986 & 1.626038 & 20.14961 & 66.41802 & 1.027970 & 6.147062 & 0.799632 & 3.831666 \\
\hline 7 & 91.57477 & 1.752276 & 20.73376 & 64.74852 & 0.982474 & 6.431196 & 0.882947 & 4.468837 \\
\hline
\end{tabular}

Variance Decomposition of COUNRISK:

\begin{tabular}{ccccccccc} 
Period & S.E. & YIELDS & BIRT7DR & BONDVALUE & COUNRISK & EXRATE & FITCHRAT & SPBIDX \\
\hline 1 & 0.170943 & 0.217572 & 0.011842 & 0.071284 & 99.69930 & 0.000000 & 0.000000 & 0.000000 \\
2 & 0.242182 & 0.706744 & 0.109828 & 0.106775 & 97.97890 & 0.949666 & 0.054005 & 0.094079 \\
3 & 0.291111 & 1.505318 & 0.220579 & 0.082012 & 96.28890 & 1.112578 & 0.222883 & 0.567730 \\
4 & 0.336326 & 4.052542 & 0.308652 & 0.215825 & 92.76025 & 1.864916 & 0.272888 & 0.524931 \\
5 & 0.374036 & 6.233012 & 0.317718 & 0.221946 & 90.42838 & 1.964216 & 0.318315 & 0.516411 \\
6 & 0.408492 & 7.532508 & 0.302748 & 0.198979 & 88.89732 & 2.312628 & 0.322298 & 0.433518 \\
7 & 0.436586 & 8.839729 & 0.355302 & 0.230582 & 87.58833 & 2.230565 & 0.314807 & 0.440686 \\
\hline
\end{tabular}

Variance Decomposition of EXRATE:

\begin{tabular}{ccccccccc} 
Period & S.E. & YIELDS & BIRT7DR & BONDVALUE & COUNRISK & EXRATE & FITCHRAT & SPBIDX \\
\hline 1 & 232.1874 & 0.189364 & 11.64074 & 3.103187 & 0.784368 & 84.28234 & 0.000000 & 0.000000 \\
2 & 292.2821 & 0.137298 & 8.156159 & 9.775615 & 0.669715 & 80.60883 & 0.652206 & 0.000174 \\
3 & 331.5899 & 2.874006 & 10.02364 & 10.02310 & 1.160212 & 74.58356 & 0.994479 & 0.341000 \\
4 & 383.1411 & 3.236503 & 7.829639 & 18.18744 & 3.598005 & 64.80155 & 1.319146 & 1.027725 \\
5 & 470.1180 & 3.409535 & 5.380093 & 25.18370 & 4.849531 & 55.64560 & 1.121409 & 4.410140 \\
6 & 527.9466 & 3.927661 & 4.729753 & 26.82237 & 6.929203 & 49.55720 & 1.386244 & 6.647572 \\
7 & 576.7322 & 4.072145 & 4.390221 & 28.49400 & 9.219381 & 44.92203 & 1.707305 & 7.194919 \\
\hline
\end{tabular}

Variance Decomposition of FITCHRAT:

Period S.E. YIELDS BIRT7DR BONDVALUE COUNRISK EXRATE FITCHRAT SPBIDX 
Jurnal Bisnis dan Manajemen, Volume 22, No. 2, September 2021, p. 127-146

\begin{tabular}{ccccccccc}
1 & 0.085145 & 0.256488 & 0.283584 & 0.004107 & 0.109199 & 0.579367 & 98.76725 & 0.000000 \\
2 & 0.124895 & 3.910751 & 0.460060 & 0.134392 & 0.089895 & 1.139284 & 93.06851 & 1.197110 \\
3 & 0.154638 & 4.236253 & 0.302998 & 0.536623 & 0.058712 & 1.217547 & 91.66222 & 1.985647 \\
4 & 0.179840 & 4.142765 & 0.376605 & 0.662957 & 0.044694 & 1.036450 & 91.37313 & 2.363394 \\
5 & 0.203231 & 3.742820 & 0.382424 & 1.004448 & 0.067491 & 0.845872 & 90.46936 & 3.487588 \\
6 & 0.224442 & 3.528396 & 0.330794 & 1.179898 & 0.066527 & 0.826627 & 89.98570 & 4.082062 \\
7 & 0.256572 & 2.771541 & 0.303015 & 1.132379 & 9.895384 & 0.655285 & 81.95887 & 3.283528 \\
\hline \multicolumn{7}{c}{ Variance Decomposition of SPBIDX: } \\
Period & S.E. & YIELDS & BIRT7DR & BONDVALUE & COUNRISK & EXRATE & FITCHRAT & SPBIDX \\
\hline & 1.082668 & 0.568434 & 1.172352 & 1.503143 & 0.008273 & 0.474814 & 1.775967 & 94.49702 \\
2 & 1.584478 & 0.274781 & 1.613765 & 1.480953 & 0.323258 & 1.166394 & 1.056682 & 94.08417 \\
3 & 1.934619 & 0.793833 & 1.645837 & 1.237562 & 0.370258 & 2.635990 & 0.711129 & 92.60539 \\
4 & 2.176327 & 2.126931 & 1.418542 & 1.027656 & 0.308554 & 2.653277 & 0.571210 & 91.89383 \\
5 & 2.316942 & 5.014258 & 1.441572 & 2.702044 & 1.823302 & 2.352662 & 0.521770 & 86.14439 \\
6 & 2.465721 & 6.393777 & 1.311752 & 3.041062 & 3.534636 & 2.264126 & 0.679116 & 82.77553 \\
7 & 2.715819 & 7.892196 & 1.295560 & 2.565244 & 7.618013 & 2.203824 & 0.575413 & 77.84975 \\
\hline
\end{tabular}

Cholesky Ordering: YIELDS BIRT7DR BONDVALUE COUNRISK EXRATE FITCHRAT SPBIDX
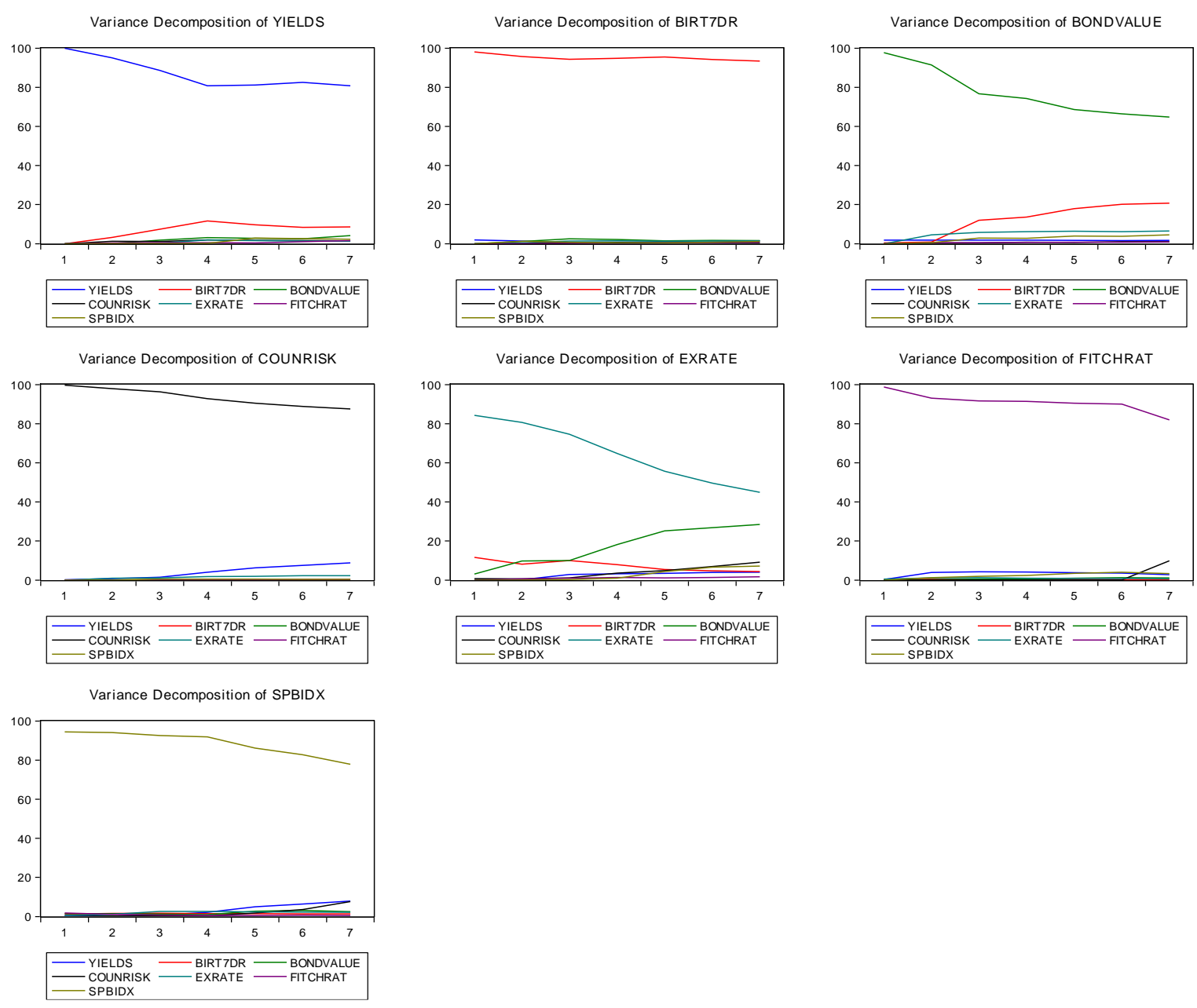

Figure 2. Determinants' FDVE Movements 
The difference in variables' contribution occurs due to the variance decomposition generates information based on the proportion of the shock's effect from one variable to another. Subsequently, the mentioned shock effect occurs during the current testing period to the next within the overall time-horizon of this study's period.

\section{CONCLUSION}

From the results and discussion above, it is uncovered that the eleven determinants used in the model are all stationary. In terms of the number of cointegrated determinants in the model against the determinant of yields, it is found that there are six determinants. Namely, the $\mathrm{BI}$ rate / seven days repo, outstanding tradable bonds, country risk based on supported export credits, exchange rates, Fitch Ratings, and S\&P regional government bond index.

Stability in the model meets the requirements processed in the VECM model. VECM estimates only use cointegrated determinants (determinants of GDP, inflation, oil price, and reserve are excluded from the VECM model). The contribution of independent variables in the variance decomposition test of successive yields from high to low is the country risk, Fitch Rating, BI rate / seven days repo, outstanding tradable government, regional bond index, and exchange rate. VECM estimation states that the $\mathrm{BI}$ rate / seven days repo and regional bond index determinants positively affect the VECM model, while the determinants of outstanding tradable GS, country risk, Fitch Ratings, and exchange rate have a negative effect on the VECM model.

The determinants of this study confirms the findings of Lim, Krznar, Lipinsky, Otani, and Wu, (2013), Muharam (2013), Sihombing et al. (2013), Soebagiyo and Panjawa (2016), and Tampubolon (2007). For the determinant of CRC and Fitch Rating (Sovereign Credit Rating), this research confirms the statement of the DGFRM Ministry of Finance of the Republic of Indonesia (2018), which states that both of these determinants affect the GS yields.

\section{RECOMMENDATIONS}

From the conclusions obtained in this study, the research can proceed by testing the interdeterminant correlations (BI rate / seven days repo, outstanding tradable GS for various tenors, Sovereign Credit Rating, regional government bonds index, exchange rate, and country risk). Future research in this field can also be extended to predicting GS yields of various tenors using the six determinants in the cointegrated category.

In a different light, there is a practical implication that emerged from this research's findings. Given that the findings of this research show that Indonesia's GS yield is interdependent with the identified determinants, it is recommended for the Indonesian government to maintain the movement of those determinants through appropriate and effective policies that 
Jurnal Bisnis dan Manajemen, Volume 22, No. 2, September 2021, p. 127-146

apply to both micro- and macro-economic

aspects of Indonesia. By which, the more stable

those determinants are, the higher the likelihood

for Indonesia's GS yield to remain positive.

\section{REFERENCES}

Adrian, N., \& Muharam, H. (2011). Analisis FaktorFaktor yang Mempengaruhi Peringkat Obligasi pada Perusahaan Manufaktur yang Terdaftar di Bursa Efek Indonesia. Universitas Diponegoro.

Agung, I. G. N. (2013). Panel Data Analysis using EViews. Chichester: John Wiley \& Sons.

ASEAN Secretariat. (2018). ASEAN Key Figures 2018. Jakarta: Association of Southeast Asian Nations (ASEAN) Secretariat. Retrieved from https://asean.org/storage/2018/12/ASEAN-KeyFigures-2018.pdf

Barr, D. G., \& Priestley, R. (2004). Expected returns, risk and the integration of international bond markets. Journal of International Money and Finance, 23(1), 71-97. https://doi.org/10.1016/j .jimonfin.2003.10.005

Chee, S. W., \& Fah, C. F. (2013). Macro-economic determinants of UK treasury bonds spread. International Journal of Arts and Commerce, 2(1), 163-172. Retrieved from https://ijac.org .uk/images/frontImages/gallery/Vol.2_No._1/13 .pdf

Codogno, L., Favero, C., \& Missale, A. (2014). Yield spreads on EMU government bonds. Economic Policy, 18(37), 503-532. https://doi.org/10.1111 /1468-0327.00114_1

DGFRM Ministry of Finance of the Republic of Indonesia. (2018). Profil Utang Pemerintah Pusat: Pinjaman dan Surat Berharga Negara. Jakarta: Ministry of Finance of the Republic of Indonesia. Retrieved from https://www.djppr .kemenkeu.go.id/\#/id/page/home

Fernandes, L. M. M., \& Borges, M. R. (2013). Interbank Linkages and Contagion Risk in the Portuguese Banking System (No. 23/2013/DE /UECE). Retrieved from https://depeco.iseg .ulisboa.pt/wp/wp232013.pdf

Gibson, H. D., Hall, S. G., \& Tavlas, G. S. (2011). The Greek financial crisis: growing imbalances and sovereign spreads (No. 124). Athens. Retrieved from http://www.bankofgreece.gr/BogEkdoseis /Paper2011124.pdf

Gonzalo, J. (1994). Five alternative methods of estimating long-run equilibrium relationships. Journal of Econometrics, 60(1), 203-233. https: //doi.org/https://doi.org/10.1016/0304-4076(94)
90044-2

Heppke-Falk, K., \& Hüfner, F. P. (2004). Expected Budget Deficits and Interest Rate Swap Spreads - Evidence for France, Germany and Italy (No. 40/2004). Frankfurt. Retrieved from https: //www.bundesbank.de/resource/blob/703196/6c af4e342491b7a2977d6e305564e4c7/mL/200412-29-dkp-40-data.pdf

Hubbard, R. G. (2001). Money, the Financial System, and the Economy (4th ed.). New Jersey: Addison Wesley.

Idham, A. (2014). Analisis Faktor Determinan yang Mempengaruhi Yield Obligasi (Studi Empiris Pemerintah Indonesia, 2009:1-2013:12). Universitas Gajah Mada.

Kim, S.-J., Moshirian, F., \& Wu, E. (2006). Evolution of international stock and bond market integration: Influence of the European Monetary Union. Journal of Banking \& Finance, 30(5), 1507-1534. https://doi.org/10.1016/j.jbankfin .2005 .05 .007

Lamedica, N., \& Reno, R. (2007). Integration of international bond markets: did anything change with EMU? Applied Economics Letters, 14(11), 829-832.

https://doi.org/10.1080/13504850600592689

Lemmen, J. (1990). Managing Government Default Risk in Federal States. Financial Markets Group. Retrieved from Financial Markets Group website: https://www.fmg.ac.uk/publications /special-papers/managing-government-defaultrisk-federal-states

Lemmen, J. J. G., \& Goodhart, C. A. E. (1999). Credit Risks and European Government Bond Markets: A Panel Data Econometric Analysis. Eastern Economic Journal, 25(1), 77-107. Retrieved from http://www.jstor.org/stable/40325907

Lim, C. H., Krznar, I., Lipinsky, F., Otani, A., \& Wu, X. (2013). The Macroprudential Framework: Policy Responsiveness and Institutional Arrangements (No. WP/13/166). Washington DC.

MacKinnon, J. G. (1996). Numerical Distribution Functions for Unit Root and Cointegration Tests. Journal of Applied Econometrics, 11(6), 601618. Retrieved from http://www.jstor.org/stable /2285154

MacKinnon, J. G., Haug, A. A., \& Michelis, L. (1999). Numerical distribution functions of likelihood ratio tests for cointegration. Journal of Applied Econometrics, 14(5), 563-577.

Mehra, Y. P. (1998). The Bond Rate and Actual Future Inflation. FRB Richmond Economic Quarterly, 84(2), 27-47. Retrieved from https: //www.richmondfed.org/publications/research/e 
conomic_quarterly/1998/spring/mehra

Muharam, H. (2013). Government Bond Yield Volatility and It's Determinants: The Case of Indonesia Government Bond. The First International Conference on Finance and Banking. Bali: Universitas Diponegoro.

Rosadi, D. (2011). Analisis Ekonomitrika \& Runtun Waktu Terapan dengan R. Yogyakarta: Penerbit Andi Yogyakarta.

Sihombing, P., Siregar, H., Manurung, A. H., \& Santosa, P. W. (2013). Determinan Yield Curve Surat Utang Negara. Jurnal Keuangan Dan Perbankan, 15(2), 68-89. Retrieved from http: //journal.perbanas.id/index.php/jkp/article/view/ 183

Sims, C. A. (1980). Macroeconomics and Reality. Econometrica, 48(1), 1-48. https://doi.org/10 $.2307 / 1912017$

Soebagiyo, D., \& Panjawa, J. L. (2016). Determinan Surat Utang Negara (SUN) dengan Pendekatan ECM. The 3rd University Research Colloquium, 54-63. Surakarta: Universitas Muhammadiyah Surakarta.

Tampubolon, G. (2007). Analisis Faktor Determinan yang Mempengaruhi Yield Obligasi: Pendekatan VAR. Universitas Indonesia.

Thomsen, A., Sandager, R., Logerman, A. V., Johanson, J. S., \& Andersen, S. H. (2013). Introduction to EViews 6.0/7.0. Aarhus: Aarhus University.

Vogelvang, B. (2005). Econometrics: Theory and Applications with EViews. Harlow: Pearson.

Wang, S., \& Yu, F. (2014). The Determinants of Chinese Local Government Bond Yields. Retrieved from https://editorialexpress.com/cgibin/conference/download.cgi?db_name=CICF2 014\&paper_id=994

Wibisono, R. (2010). Effect of Macroeconomic Variables and Speed of Balance Adjustment in Selecting Government Securities Based on Tenors. Universitas Indonesia.

Widajati, A. (2009). Inflasi dan Tingkat Bunga Terhadap Harga Obligasi Negara Ritel Yang Diterbitkan Pemerintah. Jurnal Keuangan Dan Perbankan, 13(1), 97-105. Retrieved from http: //jurnal.unmer.ac.id/index.php/jkdp/article/view /921/564

Winarno, W. W. (2015). Analisis Ekonometrika dan Statistika dengan Eviews. Yogyakarta: UPP STIM YKPN. 